\title{
Pemberian ekstrak daun sirih (Piper betle) secara topikal meningkatkan ketebalan epidermis, jumlah fibroblas, dan jumlah kolagen dalam proses penyembuhan luka pada tikus jantan galur Wistar (Rattus norvegicus)
}

\author{
${ }^{1}$ Eva F. Palumpun \\ ${ }^{2}$ Anak A. G. P. Wiraguna \\ ${ }^{3}$ Wimpie Pangkahila
}

\author{
${ }^{1}$ Program Pascasarjana Anti-Aging Medicine, \\ ${ }^{2}$ Departemen Penyakit Kulit dan kelamin, \\ ${ }^{3}$ Departemen Andrologi dan Seksologi, Fakultas Kedokteran Universitas Udayana \\ Email: eva.palumpun@gmail.com
}

\begin{abstract}
This study was aimed to prove that topical betel (Piper betle) leaf extract adinistration could increase epidermal thickness, fibroblasts, and collagen amount in wound healing process of male Wistar rats (Rattus norvegicus). Subjects were 36 Wistar rats (Rattus norvegicus) with inclusion criteria, as follows: healthy, aged 3-4 months, weighing 200-250 g, divided into two groups with 18 rats each. The first group, the control group (P0), was treated with oral amoxicillin $3 \times 10 \mathrm{mg} /$ day for 3 days and one drop $(50 \mu \mathrm{l})$ of $10 \%$ povidine iodine topically $2 \mathrm{x} /$ day for 14 days, and the second group, the treatment group (P1), treated with oral amoxicillin $3 \times 10$ $\mathrm{mg} /$ day for 3 days and one drop $(50 \mu \mathrm{l})$ of $10 \%$ betel leaf (Piper betle) extracttopically $2 \mathrm{x} /$ day for 14 days. Samples of skin tissue were processed for histological slides by using hematoxylin-eosin staining to check the epidermal thickness and fibroblast, meanwhile Picro sirius red staining to check the collagen amount. Microscopic examinations showed that the average epidermal thickness in P0 group was $24.72 \pm 14.91 \mu \mathrm{m}$, whereas in the P1 group was $56.75 \pm 23.04 \mu \mathrm{m}(P$ $<0.01)$. The number of fibroblasts in P0 group was 75,45 $\pm 32,52$ cells/visual field meanwhile of P1 group was $95,67 \pm 22,51$ cells/visual field $(P<0.05)$. The average of collagen amount in P0 group was $65.27 \pm 7.13 \%$ while in P1 group was $83.09 \pm 2.59 \%(P<0.01)$. Conclusion: Topical administration of $10 \%$ betel (Piper betle) leaf extract could increase epidermal thickness, fibroblasts, and collagen in wound healing process of male Wistar rats (Rattus norvegicus).
\end{abstract}

Keywords: betel leaf, epidermis, fibroblast, collagen, wound

\begin{abstract}
Abstrak: Tujuan penelitian ini ialah untuk membuktikan bahwa pemberian ekstrak daun sirih (Piper betle) meningkatkan ketebalan epidermis, jumlah fibroblas, dan jumlah kolagen dalam proses penyembuhan luka pada tikus jantan galur Wistar (Rattus norvegicus). Subjek penelitian ialah 36 ekor tikus jantan galur Wistar (Rattus norvegicus) dewasa dan sehat, berumur 3-4 bulan, dengan berat badan 200-250 gr, yang terbagi menjadi 2 (dua) kelompok masing-masing berjumlah 18 ekor tikus. Kelompok pertama ialah kelompok kontrol (P0) diberikan amoksisilin oral $3 \times 10 \mathrm{mg} /$ hari selama 3 hari serta povidine iodine 10\% topikal 1 tetes $(50 \mu \mathrm{l}) 2 \mathrm{x} /$ hari selama 14 hari (P0). Kelompok kedua ialah kelompok perlakuan (P1) diberi amoksisilin oral $3 \times 10$ $\mathrm{mg} /$ hari selama 3 hari serta ekstrak daun sirih (Piper betle) konsentasi 10\% secara topikal 1 tetes $(50 \mu \mathrm{l}), 2 \mathrm{x} /$ hari selama 14 hari. Jaringan kulit diambil dan dibuat preparat dengan pewarnaan hematoksilin-eosin untuk pemeriksaan ketebalan epidermis dan jumlah fibroblas, serta pewarnaan Picro sirius red untuk pemeriksaan jumlah kolagen. Hasil pemeriksaan mikroskopik menunjukkan rerata tebal epidermis pada kelompok P0 24,72 $\pm 14,91 \mu \mathrm{m}$ dan pada kelompok P1 $56,75 \pm 23,04 \mu \mathrm{m}(P<0,01)$. Rerata jumlah fibroblas pada kelompok P0 $75,45 \pm 32,52$ sel/lapang pandang dan pada kelompok P1 95,67 $\pm 22,51$ sel/lapang pandang $(P<0,05)$. Rerata jumlah

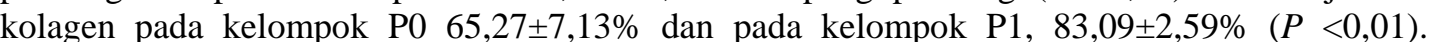
Simpulan: Pemberian ekstrak daun sirih (Piper betle) konsentrasi 10\% secara topikal dapat meningkatkan ketebalan epidermis, jumlah fibroblas, dan jumlah kolagen pada luka tikus jantan galur Wistar (Rattus norvegicus).
\end{abstract}

Kata kunci: daun sirih, epdermis, fibroblas, kolagen, luka 
Menjadi tua adalah suatu proses yang tidak terjadi begitu saja Telah banyak ilmuwan yang melakukan penelitian untuk menghambat dan memperlambat proses penuaan karena pada dasarnya manusia tidak ingin menjadi tua dan menjadi tua hampir selalu dikaitkan dengan kelemahan, ketidakberdayaan atau kekurangan dalam hal lainnya. ${ }^{1}$ Fungsi kulit manusia menurun seiring usia, termasuk fungsi penyembuhan luka. Dengan adanya berbagai perubahan struktur dan fungsi yang mengganggu integritas kulit, sering sekali penyembuhan luka terhambat sampai dengan terbukanya kembali luka yang sudah mulai menyembuh., ${ }^{2,3}$

Proses penyembuhan luka merupakan proses biologis yang terjadi di dalam tubuh, ${ }^{4}$ melibatkan rangkaian proses yang rumit, rentan, dan sangat mungkin terjadi gangguan ataupun kegagalan, sehingga diperlukan kondisi yang optimal untuk mendapatkan penyembuhan yang baik. Pada proses penyembuhan luka, terjadi serangkaian interaksi antara berbagai jenis sel mediator sitokin, dan matriks ekstrasel terangkum dalam tiga fase yang saling tumpang tindih, yaitu fase inflamasi, fase proliferasi, serta fase remodeling jaringan. ${ }^{5}$

Tujuan dari manajemen luka ialah penyembuhan luka dalam waktu sesingkat mungkin, meminimalkan kerusakan jaringan, penyediaan perfusi jaringan yang cukup dan oksigenasi, serta nutrisi yang tepat untuk jaringan luka. ${ }^{6}$ Pengobatan dari luka bertujuan untuk mengurangi faktorfaktor risiko yang menghambat penyembuhan luka, mempercepat proses penyembuhan dan menurunkan kejadian luka yang terinfeksi. ${ }^{7}$

Penggunaan tanaman sebagai obat sudah lama dikenal masyarakat Indonesia, hanya saja dasar penggunaan tanaman sebagai obat dan khasiatnya diketahui berdasarkan pengalaman orang-orang tua terdahulu, tanpa mengetahui kandungan dari tanaman tersebut. Salah satu tanaman obat yang cukup dikenal masyarakat ialah daun sirih (Piper betle). Daun sirih bermanfaat sebagai antiseptik dan vulnerary yaitu menyembuhkan luka. ${ }^{8}$
Daun sirih mengandung saponin, flavonoid, tanin, dan minyak atsiri. Saponin, flavonoid serta tanin dapat membantu proses penyembuhan luka karena berfungsi sebagai antioksidan dan antimikroba yang memengaruhi penyambungan luka juga mempercepat epitelisasi. ${ }^{9,10}$ Fannani dan Nugroho $^{11}$ menunjukkan bahwa ekstrak etanol daun sirih konsentrasi $10 \%$ topikal pada luka iris selama 14 hari dapat mengingkatkan kecepatan penyembuhan luka iris.

Selain kaya akan zat aktif, daun sirih sangat mudah didapatkan dan sudah sejak dahulu banyak digunakan sebagai obat tradisional. Kesembuhan luka yang ditandai dengan penutupan luka saja tidak cukup, tetapi akan lebih baik jika proses kesembuhan luka terjadi dengan proses regenerasi yang tepat sehingga diperoleh hasil kesembuhan sempurna tanpa cacat. Pada penelitian ini dilakukan pemeriksaan mikroskopik terhadap ketebalan epidermis, jumlah fibroblas, dan jumlah kolagen dari proses penyembuhan luka yang diaplikasikan ekstrak daun sirih.

\section{METODE PENELITIAN}

Penelitian ini bertujuan untuk membuktikan bahwa pemberian ekstrak daun sirih (Piper betle) secara topikal dapat meningkatkan ketebalan epidermis, jumlah fibrolas, dan jumlah kolagen pada luka tikus jantan galur Wistar (Rattus norvegicus). Jenis penelitian ini ialah eksperimental dengan menggunakan completely randomized post test only control group design.

Subyek penelitian ialah 36 ekor tikus galur Wistar (Rattus norvegicus) dewasa dan sehat, berumur 3-4 bulan, dengan berat badan 200-250 gram, yang terbagi menjadi 2 kelompok masing-masing berjumlah 18 ekor tikus. Kelompok pertama ialah kelompok kontrol (P0) yang diberikan amoksisilin oral $3 \times 10 \mathrm{mg}$ /hari selama 3 hari serta povidine iodine $10 \%$ topikal 1 tetes $(50 \mu \mathrm{l})$ 2x/hari selama 14 hari. Kelompok kedua ialah kelompok perlakuan (P1) yang diberikan amoksisilin oral $3 \times 10$ $\mathrm{mg} /$ hari selama 3 hari serta ekstrak daun 
sirih (Piper betle) dengan konsentrasi 10\% secara topikal 1 tetes $(50 \mu \mathrm{l}), 2 \mathrm{x} /$ hari selama 14 hari. Pada hari ke 14, diambil sampel kulit dari luka untuk dibuat preparat histopatologik, sebelumnya tikus telah dianestesi terlebih dahulu.

Data dianalisis menggunakan SPSS Versi 17.00 meliputi analisis deskriptif, uji normalitas data dengan uji Shapiro-Wilk, uji homogenitas dengan uji Levene, uji komparasi dengan independent sample $T$ Test.

\section{HASIL PENELITIAN DAN BAHASAN}

Data hasil penelitian pada variabel ketebalan epidemis ialah ketebalan epidermis pada masing-masing kelompok perlakuan, diperiksa sesuai karakter patologik kulit. Ketebalan epidermis diamati dan diukur dengan menggunakan metode morfometri, mikroskop yang dihubungkan dengan alat Optilab dengan pembesaran lensa obyektif 40x. Gambar tersebut diolah dengan piranti lunak Image Raster, yaitu dengan mengukur tebal epidermis dalam satuan $\mu \mathrm{m}$. Tebal epidermis adalah ukuran ketebalan lapisanlapisan epidermis yang terbentuk pada daerah luka (Gambar 1).

Data hasil penelitian pada variabel jumlah fibroblas ialah pengamatan jumlah fibroblas pada kedua kelompok. Pengamatan hasil jumlah fibroblas pada preparat dengan pewarnaan HE, dilakukan dengan mencari daerah sebaran fibroblas yang relatif merata lalu menggunakan lensa obyektif 10x gambar preparat difoto. Dengan menggunakan bantuan Image Raster dibuat kotak dengan ukuran $50 \mu \mathrm{m}$ x $50 \mu \mathrm{m}$, lalu dihitung jumlah fibroblas di dalam kotak yang sudah dibuat secara manual (Gambar 2).

Pengamatan jumlah kolagen pada preparat dengan pewarnaan Picro sirius red, kemudian dilakukan dengan metode analisis digital. Sediaan diamati dengan pembesaran 400 kali menggunakan mikroskop Olympus CX41, dan difoto dengan kamera Optilab Pro. Jumlah kolagen dihitung sebagai persentase pixel area kolagen yang berwarna merah disbanding-kan dengan pixel area seluruh jaringan (Gambar 3).

Terjadinya peningkatan regenerasi jaringan luka oleh ekstrak daun sirih dimungkinkan karena kandungan tanin dalam daun sirih. Tanin merangsang pertumbuhan epidermis dan membantu reepitelisasi dengan cara mengendapkan lipid protein kompleks dan mempercepat pembentukan keropeng fleksibel yang menutup luka. Hasil penelitian ini didukung oleh penelitian sebelumnya yang menunjukkan bahwa pemberian ekstrak metanol 5\% daun sirih (Piper betle) selama 12 hari dapat meningkatkan epitelisasi lebih baik dibandingkan kelompok kontrol pada mencit galur Swiss. ${ }^{12}$
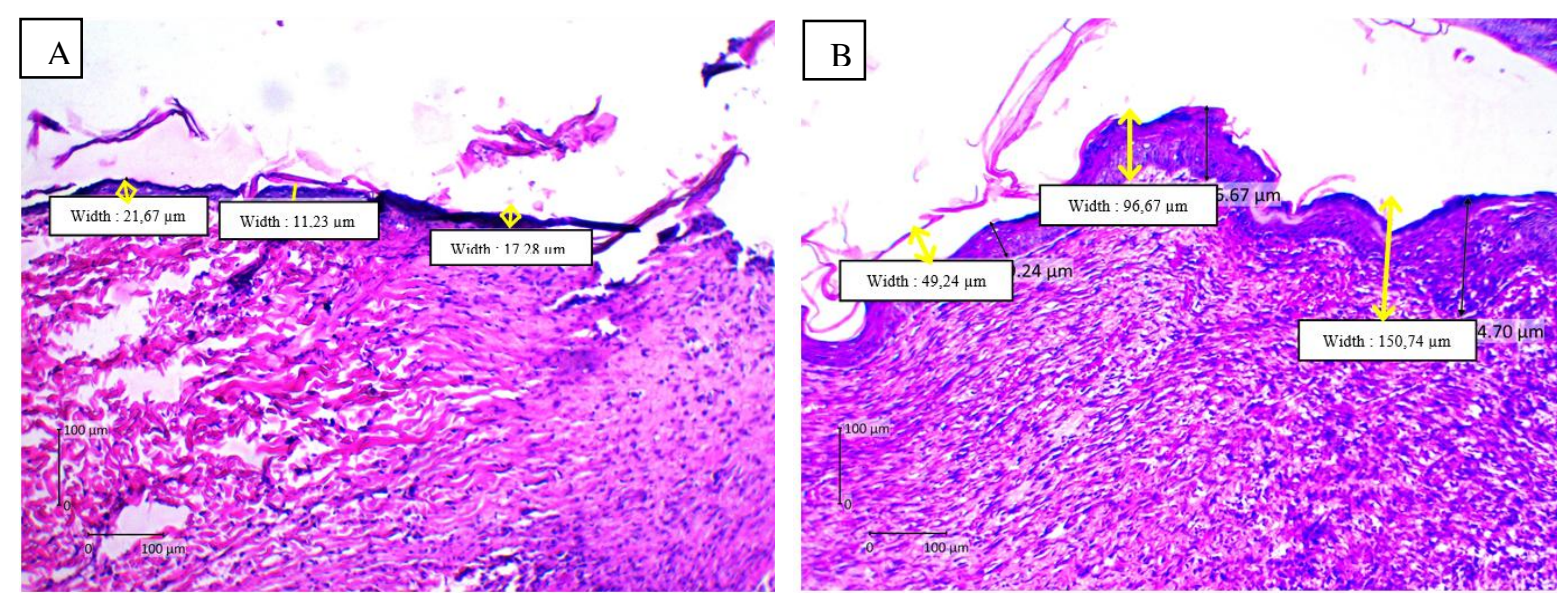

Gambar 1. Histopatologik ketebalan epidermis. A) Kelompok kontrol (P0); B) Kelompok perlakuan (P1); dengan pembesaran 40X, tampak lapisan epidermis (panah kuning) 

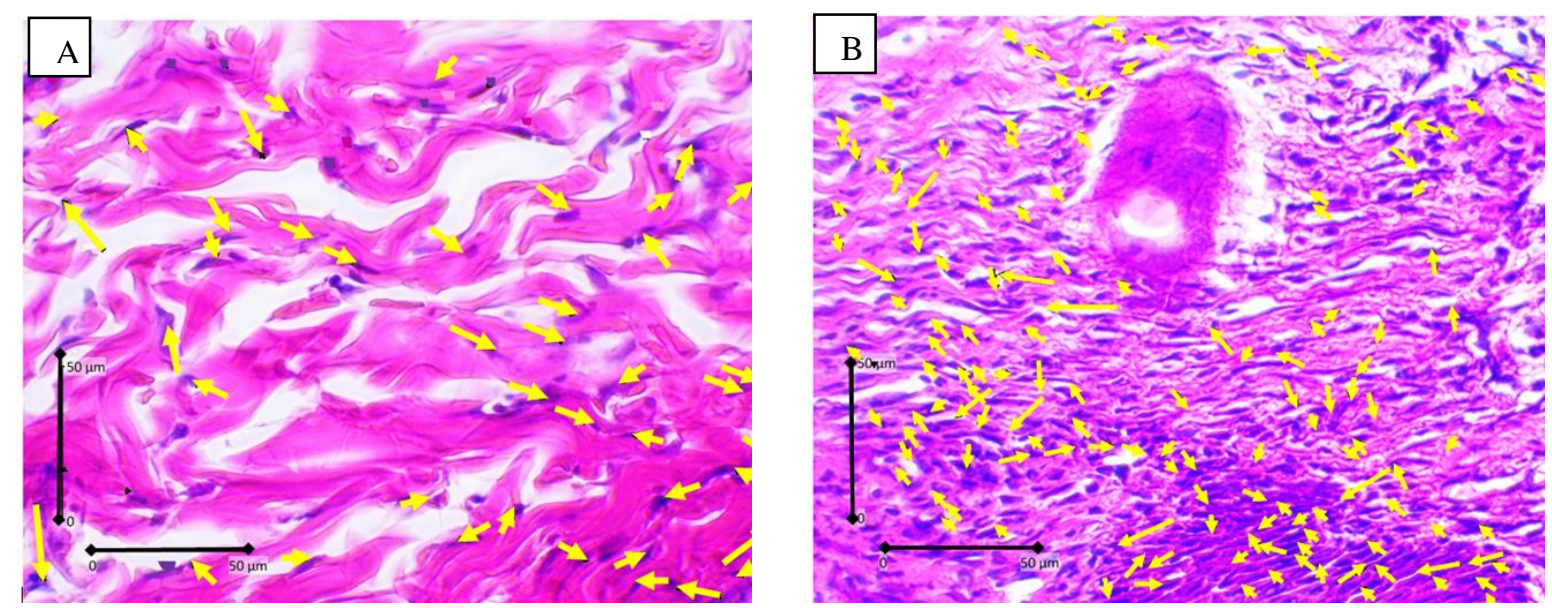

Gambar 2. Fibroblas (panah kuning). A) Kelompok kontrol (P0), fibroblas tampak tersebar tidak merata dan jarang; B) Kelompok perlakuan (P1), fibroblas tampak tersebar merata dan padat
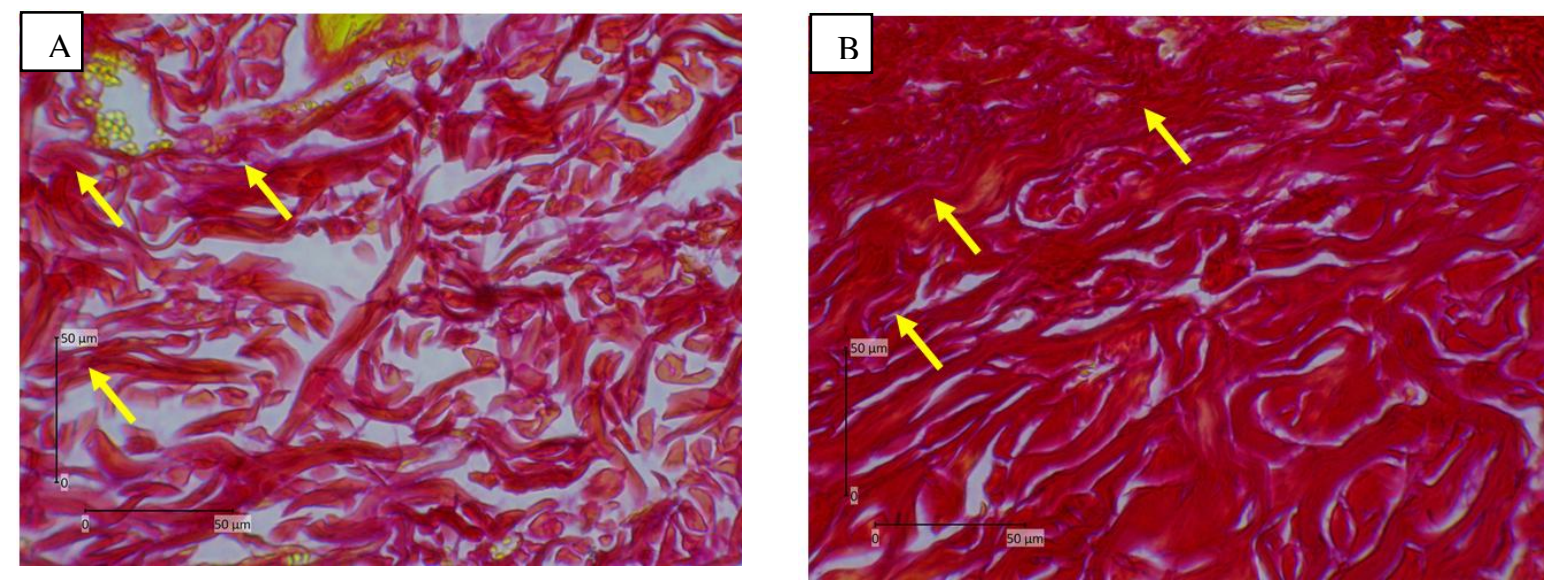

Gambar 3. Kolagen (panah kuning) dengan pembesaran 400x. A) Kelompok kontrol (P0), serat kolagen tampak tipis, tidak teratur, dan banyak celah kosong; B) Kelompok perlakuan (P1), serat kolagen tampak padat, teratur dan tebal

Penelitian lain juga menunjukkan bahwa ekstrak daun sirih (Piper betle) dosis 50 $\mathrm{mg} / \mathrm{kg}$ BB secara oral dapat mempercepat proses epitelisasi luka pada tikus SpragueDawley yang diinduksi diabetes. ${ }^{13}$ Epitelisasi merupakan salah satu fase utama dalam proses penyembuhan luka, disamping pembentukan jaringan granulasi dengan kolagen dan jaringan ikat protein deposisi dan angiogenesis. ${ }^{5}$

Selain itu, daun sirih juga terbukti meningkatkan jumlah fibroblas dan kolagen karena kandngan tanin dan flavonoid. Tanin mempunyai aktivitas mekanisme seluler yaitu membersihkan radikal bebas dan oksigen reaktif, meningkatkan penyambungan luka, serta meningkatkan pembentukan pembuluh darah kapiler serta aktivasi fibroblas. Flavonoid bekerja dengan cara menurunkan lipid peroksidasi sehingga terjadi peningkatan viabilitas serat kolagen. Luka yang diberi ekstrak daun sirih dengan kandungan zat aktif tersebut akan merangsang proliferasi fibroblas, dan fibroblas yang teraktivasi akan menyekresi kolagen dan membentuk jaringan granulasi. Terbentuknya jaringan granulasi yang sempurna akan menutup permukaan luka. Pembentukan jaringan granulasi mengakhiri fase proliferasi proses penyembuhan luka dan dimulai pematangan dalam fase remodeling.

Penelitian terdahulu juga menyebutkan 
bahwa perlakuan ekstrak daun sirih (Piper betle) $10 \%$ selama 21 hari dapat meningkatkan jumlah kolagen dan mempercepat proses penyembukan luka. ${ }^{14}$ Selain itu, hasil penelitian ini didukung penelitian Ghazali et al. ${ }^{12}$ yang menemukan bahwa ekstrak metanol 5\% daun sirih (Piper betle) selama 12 hari dapat meningkatkan jumlah kolagen pada mencit galur Swiss, diiringi dengan peningkatan jumlah fibroblas.

Daun sirih mengandung saponin, flavonoid, tannin, dan minyak atsiri. Kandungan saponin, flavonoid, serta tanin dapat membantu proses penyembuhan luka karena berfungsi sebagai antioksidan dan antimikroba yang memengaruhi penyambungan luka, dan juga mempercepat epitelisasi. ${ }^{9,10}$ Senyawa aktif ini berperan sebagai antioksidan yang berpengaruh pada kontraksi luka, meningkatkan kecepatan epitelisasi, dan juga steroid dalam hal ini sterol atau steroid alkohol yang berpengaruh pada penyembuhan luka serta berfungsi sebagai antioksidan dan pembasmi radikal bebas, mengurangi lipid peroksidasi, mengurangi nekrosis sel, dan meningkatkan vaskularisasi. ${ }^{7,15-17}$ Aktivitas antioksidan yang tinggi ini dapat mempercepat penyembuhan luka karena dapat menstimulasi produksi antioksidan endogen pada situs luka dan menyediakan lingkungan yang kondusif untuk terjadinya penyembuhan luka. ${ }^{18}$

Kandungan flavonoid pada tumbuhan herbal telah banyak dibuktikan dapat mempercepat penyembuhan luka dengan meningkatkan proses epitelisasi. Epitelisasi yang merupakan proses pembaharuan epitel setelah terjadinya luka, melibatkan proliferasi dan migrasi sel epitel menuju pusat luka dan kontraksi luka disebabkan oleh aksi miofibroblas. ${ }^{19}$ Flavonoid telah dibuktikan dapat meningkatkan migrasi dan proliferasi sel epitel, pembentukan jaringan granulasi, serta meningkatkan migrasi dan aktivitas miofibroblas. ${ }^{20}$ Pemberian flavonoid oral dapat meningkatkan epitelisasi dan pembentukan jaringan granulasi pada luka yang dapat terjadi karena peningkatan produksi kolagen dan angiogenesis pada luka. ${ }^{21-23}$ Proses ini merupakan indikator proses penyembuhan luka dan menunjukkan bahwa flavonoid dapat merangsang mekanisme yang terkait dengan penyembuhan luka dan regenerasi jaringan. Studi yang dilakukan Muralidhar et al. ${ }^{20}$ menunjukkan bahwa flavonoid secara nyata dapat mempercepat proses penyembuhan luka dengan peningkatan laju kontraksi luka, penurunan periode epitelisasi, peningkatan deposisi kolagen, dan terbentuknya jaringan granulasi.

Tujuan dari manajemen luka ialah penyembuhan luka dalam waktu sesingkat mungkin, meminimalkan kerusakan jaringan, penyediaan perfusi jaringan yag cukup dan oksigenasi nutrisi yang tepat untuk jaringan luka, sehingga mengurangi faktor resiko yang dapat menghambat penyembuhan luka dan menurunkan angka kejadian luka yang terinfeksi. Dengan dilakukannya pengobatan yang tepat diharapkan tidak hanya terjadi penyembuhan yang cepat, tapi juga terjadi proses regenerasi yang tepat.

Lebih lanjut diharapkan pemberian ekstrak daun sirih dapat digunakan sebagai terapi pengobatan luka pada manusia jika sudah teruji secara klinis. Keterbatasan penelitian ini ialah tidak meneliti efek samping pada pemberian topikal ekstrak daun sirih. Selain itu, penelitian dilakukan selama fase inflamasi dan proliferasi dalam jangka waktu 14 hari dimana luka pada kedua kelompok tikus sudah tertutup jaringan granulasi. sehingga tidak dilakukan pengamatan fase remodeling paska penyembuhan luka dan belum diketahui secara pasti akan menimbulkan jaringan parut atau tidak. Diharapkan dapat dilakukan penelitian lebih lanjut tentang efek samping pemberian ekstrak daun sirih serta pengamatan pada fase remodeling untuk mengetahui apakah terjadi pembentukan jaringan parut atau tidak.

\section{SIMPULAN}

Berdasarkan hasil penelitian ini, dapat disimpulkan bahwa pemberian ekstrak daun sirih (Piper betle) dengan konsentrasi $10 \%$ secara topikal dapat meningkatkan 
ketebalan epidermis serta jumlah fibroblas dan kolagen pada luka tikus (Rattus norvegicus) galur Wistar jantan.

\section{DAFTAR PUSTAKA}

1. Pangkahila W. Anti-Aging Tetap Muda dan Sehat. Jakarta: Kompas Media Nusantara, 2011; p. 1-243.

2. Gist S, Tio-Matos I, Falzgraf S, Cameron $\mathbf{S}$, Beebe $\mathbf{M}$. Wound care in the geriatric client. Clin Interv Aging. 2009;4:269-87.

3. Minimas DA. Aging and its influence on wound healing. Wounds UK. 2007; 3(1).

4. Guo S, DiPietro LA. Factors affecting wound healing. J Dent Res. 2010; 89(3):219-29.

5. Broughton G, Janis JE, Attinger CE. 2006. The basic science of wound healing. Plast Reconstr Surg. 2006; 117[Suppl 7]:12S-34S.

6. Reddy GAK, Priyanka B, Saranya CS, Kumar CKA. Wound healing potential of Indian medicinal plants. Int J Pharm Rev Res. 2012;2(2):75-8.

7. Soni H, Singhai AK. A recent update of botanicals for wound healing activity. Int Res J Pharm. 2012;3(7):1-6.

8. Moeljanto RD, Mulyono. Khasiat dan Manfaat Daun Sirih Obat Mujarab dari Masa ke Masa (1st ed). Semarang: Agromedia Pustaka, 2003; p. 1-18.

9. Senthil P, Kumar A, Manasa M, Sravanthi K, Deepa D. Wound healing activity of alcoholic extract of "Guazuma ulmifolia" leaves on albino Wistar rats. Int $\mathbf{J}$ Pharm Bio Sci. 2011;2(4):34-8.

10.Saroja M, Santhi R, Annapoorani S. Wound healing activity of flavonoid fraction of Cynodon dactylon in Swiss albino mice. Int Res $\mathbf{J}$ Pharm. 2012;3(2):230-1.

11.Fannani MZ, Nugroho T. Pengaruh salep ekstrak etanol daun sirih (Piper betle) terhadap penyembuhan luka iris pada tikus putih jantan (Rattus novergicus). Jurnal Kedokteran dan Kesehatan Indonesia. 2014;6(1):19-26.

12.Lien LT, Tho NT, Ha DM, Hang PL, Nghia PT, Thang ND. Influence of phytochemicals in piper betle linn leaf extract on wound healing. Burns \& Trauma. 2015; 3(23):1-8
13. Ghazali NA, Elmy A, Yuen LC, Sani NZ, Das S, Suhaimi F, Thent ZC. Piper betel leaves induces wound healing activity via proliferation of fibroblasts and reducing $11 \beta$ hydroxysteriod dehydrogenase-1 expression in diabetic rat. J Ayurveda Integr Med. 2016;7(4):198-208.

14. Nilugal KC, Perumal K, Ugander RE, Chittor AI. Evaluation of wound healing activity of piper betle leaves and stem extract in experimental Wistar rats. Am J Pharm Tech Res. 2014;4(3):443-52.

15. Chaudhari M, Mengi S. Evaluation of phytoconstituents of Terminalia arjuna for wound healing activity in rats. Phytother Res. 2006;20(9):799-805.

16.Karodi R, Jadhav M, Rub R, Bafna A. Evaluation of the wound healing activity of a crude extract of Rubia cordifolia L. (Indian madder) in mice. Int J Appl Res in Nat Prod. 2009; 2(2):12-8.

17. Thakur R, Jain N, Pathak R, Sandhu SS. Practices in wound healing studies of plants. Evid Based Complement Alternat Med. 2011;2011:438056.

18. Ahmed KA, Abdulla MA, Mahmoud FM. Wound healing potential of Phyllanthus niruri leaf extract in experimental rats. Mid-East J Sci Res. 2012;11(11):1614-8.

19. Mohan H. Inflammation and healing. In: Textbook of Pathology (5th ed), ISBN:81-8061-368-2. New Delhi: Jaypee Brothers, 2005; p. 133-79.

20.Muralidhar A, Babu KS, Sankar TR, Reddanna P, Latha J. Wound healing activity of flavonoid fraction isolated from the stem bark of Butea monosperma (Lam) in albino wistar rats. Eur J Experimental Biol. 2013; 3(6):1-6.

21.Bairy KL, Rao CM. Wound healing profiles of Ginkgo biloba. J Natural Remedies. 2001;1:25-7.

22.Swamy KH, Krishna V, Shankarmurthy K, Rahiman AB, Mankani KL, Mahadevan KM. Wound healing activity of embelin isolated from the ethanol extract of leaves of Embelia ribes Burm. J Ethnopharmacol. 2007; 109:529-34.

23.Harish BG, Krishna V, Kumar HS, 
Ahamed KB, Sharath R, Swamy

KH. Wound healing activity and docking of glycogen-synthase-kinase-
3 - $\beta$-protein with isolated triterpenoid lupeol in rats. Phytomedicine. 2008; 15: 763-767. 